\title{
Promising Electrochemical Study of Titanate Based Anodes in Direct Carbon Fuel Cell Using Walnut and Almond Shells Biochar Fuel
}

Amjad Ali ${ }^{1,2}$, Rizwan Raza ${ }^{1,3^{*}}$, Asia Rafique ${ }^{1}$, Farah Alvi ${ }^{1}$, Muhammad Kaleem Ullah ${ }^{1}$, Abdul Hamid $^{4}$, Jung-Sik Kim ${ }^{5 *}$

${ }^{1}$ Department of Physics, COMSATS University Islamabad, Lahore Campus, Pakistan

${ }^{2}$ Department of Physics, University of Okara, Pakistan

${ }^{3}$ Department of Energy Technology, Royal Institute of Technology (KTH), 10044 Stockholm, Sweden

${ }^{4}$ Department of Chemistry, University of Okara, Pakistan

${ }^{5}$ Department of Aeronautical and Automotive Engineering, Loughborough University, UK, LE11 $3 T U$

\section{Email: razahussaini786@gmail.com / amjad09pu@yahoo.com}

\begin{abstract}
The direct carbon fuel cell (DCFC) is an efficient device that converts the carbon fuel directly into electricity with $100 \%$ theoretical efficiency contrary to practical efficiency around $60 \%$. In this paper four perovskite anode materials $\mathrm{La}_{0.3} \mathrm{Sr}_{0.7} \mathrm{M}_{0.07} \mathrm{Ti}_{0.93} \mathrm{O}_{3-\delta}(\mathrm{M}=\mathrm{Ni}, \mathrm{Fe}, \mathrm{Co}, \mathrm{Zn})$ have been prepared using sol-gel technique to measure the performance of the device using solid fuel. These materials have shown reasonable stability and conductivity at $700{ }^{\circ} \mathrm{C}$. Further structural analysis of as-prepared anode material using XRD technique reveals a single cubic perovskite structure with average crystallite size roughly $47 \mathrm{~nm}$. Walnut and almond shells biochar have also been examined as a fuel in DCFC at the temperature range $400-700{ }^{\circ} \mathrm{C}$. In addition, Elemental analysis of walnut and almond shells has shown high carbon content and low nitrogen and sulfur contents in the obtained biochar. Subsequently, the superior stability of asprepared anode materials is evident by thermogravimetric analysis in pure $\mathrm{N}_{2}$ gas atmosphere. Conversely, the LSFT anode has shown the highest conductivity of $7.53 \mathrm{Scm}^{-1}$ at $700{ }^{\circ} \mathrm{C}$. The obtained power density for LSFT $\mathrm{O}_{3-\delta}$ composite anode mixed in sub-bituminous coal, walnut and almond shells biochar is of $68,55,48 \mathrm{mWcm}^{-2}$ respectively. A significant improvement in performance of DCFC $\left(78 \mathrm{mWcm}^{-2}\right)$ was achieved.
\end{abstract}

Keywords: Perovskite, Walnut Shell, Almond Shells, Electrical Conductivity, Power Density. 


\section{Introduction}

Fuel cell technology is famous for rendering clean, environmental friendliness and higher efficiency. By comparison DCFC has many advantages, particularly solid carbon is easy to transport, store and readily available from coal, coke, biomass and waste materials. DCFC has $100 \%$ theoretical efficiency, with more than $60 \%$ practical efficiency with low $\mathrm{CO}_{2}$ production [1-4]. In general, DCFCs directly transform chemical energy of carbon into electricity without any intermediate reformer, at higher efficiency than coal combustion power plants [5]. Further, DCFC have been famously categorized into molten hydroxide, molten carbonate and solid oxide, but due to minimal risk of corrosion solid oxide electrolyte is regarded the best candidate to separate anode and cathode from each other [6-8]. In contrast, fuel cell design based on molten media in anode is likely to have rapid corrosion rate that can cause corrosion in the different parts of the cell, thus a solid carbon anode is more viable. Conventionally in fuel cells, the electrochemical reaction occurs at a triple phase boundary, with the gas or liquid diffused into the porous anode surface, but in DCFCs, the fuel is solid, which lowers this, as gasification of carbon is not easily accomplished. In DCFCs the continuous supply of solid fuel at anode/electrolyte interface is a key issue [9]. The conversion of carbon directly to electrical energy in fuel cells was established by William W. Jacques in 1896 [10]. The working principal of DCFC is shown in Fig. 1. The electrochemical reaction takes place at anode in the DCFCs is [11]:

$$
\mathrm{C}+2 \mathrm{O}^{2-} \rightarrow \mathrm{CO}_{2}+4 \mathrm{e}^{-}
$$

Cathode reaction is:

$$
\mathrm{O}_{2}+4 \mathrm{e}^{-} \rightarrow 2 \mathrm{O}^{2-}
$$

The overall cell reaction mechanism in the cell is:

$$
\mathrm{C}+\mathrm{O}_{2} \rightarrow \mathrm{CO}_{2}
$$

However, the extensively used solid electrolytes for DCFCs are yttrium stabilized zirconia and doped ceria $[12,13]$. These electrolytes showed good performance at temperatures exceeding $700{ }^{\circ} \mathrm{C}$ but at such high temperature, this decreased the energy conversion efficiency due to fast degradation, sealing issues and slow start-up time [13]. Moreover, lowering the 
temperature is a key task to commercialize the DCFCs, which can be achieved by preparing highly conducting electrolytes and cathodes having high oxidation reduction reaction at lower temperature $[14,15]$.

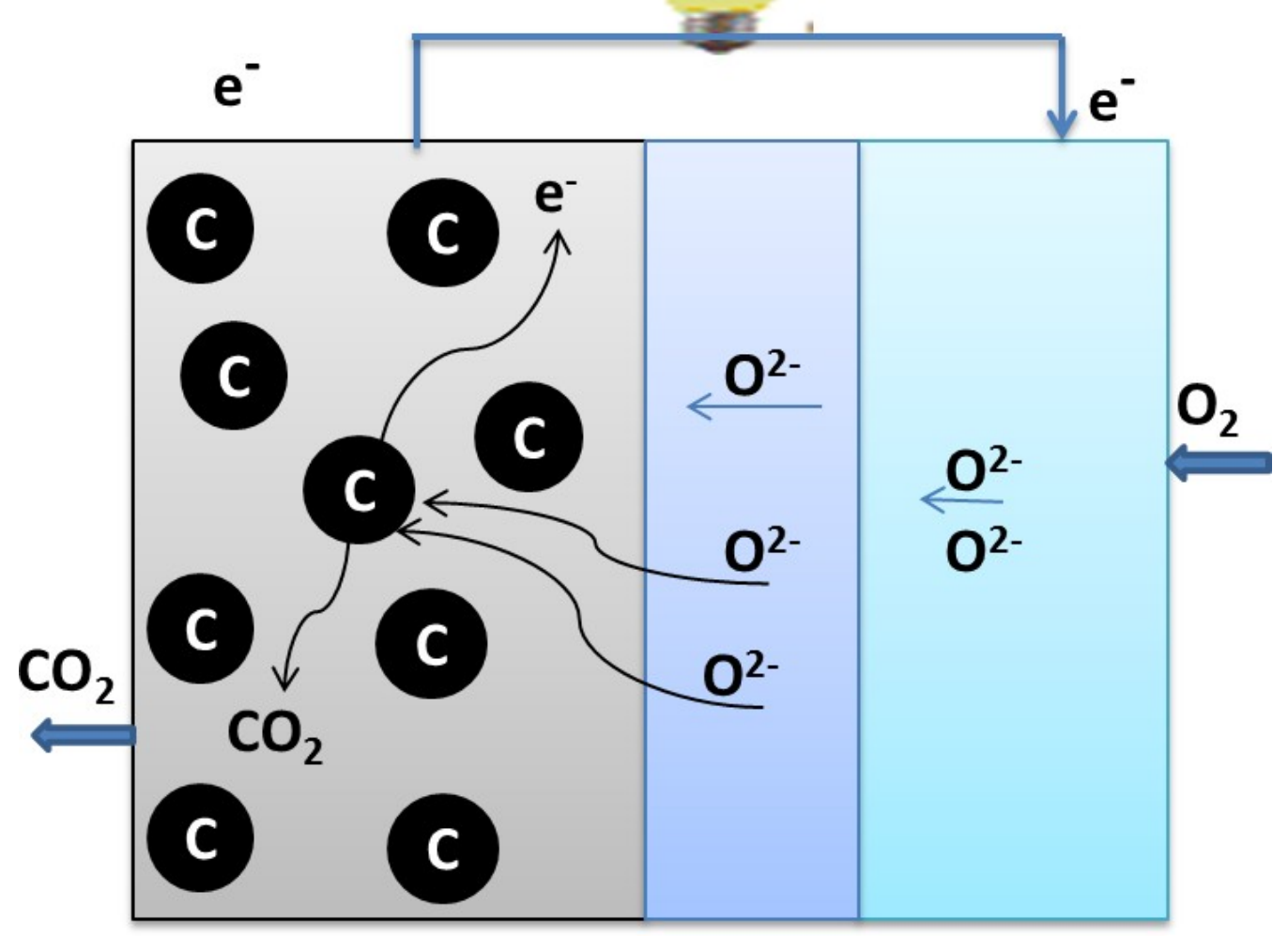

Fig. 1: Working principle of direct carbon fuel cell

However, the extensively used solid electrolytes for DCFCs are yttrium stabilized zirconia and doped ceria $[12,13]$. These electrolytes showed good performance at temperatures exceeding $700{ }^{\circ} \mathrm{C}$ but at such high temperature, this decreased the energy conversion efficiency due to fast degradation, sealing issues and slow start-up time [13]. Moreover, lowering the temperature is a key task to commercialize the DCFCs, which can be achieved by preparing highly conducting electrolytes and cathodes having high oxidation reduction reaction at lower temperature $[14,15]$.

Conversely many researchers have explored the large number of ceramic anodes (ceria and titania) for hydrocarbon fuels. [16-19]. The ceria based anodes have oxygen storage capacity and good catalytic activity, but the electronic conductivity is very low. Titanate based anodes 
possess good tolerance for sulfur and $\mathrm{H}_{2} \mathrm{~S}$ impurities, better stability and reasonable conductivity but low catalytic activity towards fuel oxidation. To enhance the electronic conductivity, noble metals such as $\mathrm{Ni}, \mathrm{Fe}, \mathrm{Co}$ are doped on the $\mathrm{B}$ site, resulting in high electronic conductivity $[20,21]$. Among the many approaches that have been employed to increase the stability and generate more promising catalytic performance [22-25] is doping of transition metal in B-site to improve the electrochemical performance [26].

Several types of DCFCs were prepared by Cooper et al. using carbon anode fuel mixed in molten carbonate electrolytes and found a maximum power density of $100 \mathrm{~mW} \mathrm{~cm} \mathrm{~cm}^{-2}$ at $800{ }^{\circ} \mathrm{C}$ $[27,28]$. Zecevic et al. prepared a DCFC using molten hydroxide electrolyte along with Fe-Ti alloy container cathode and carbon rod anode observed the power density $40 \mathrm{~mW} \mathrm{~cm}{ }^{-2}$ at $630{ }^{\circ} \mathrm{C}$ [29]. Molten hydroxide electrolyte has high ionic conductivity as well as reactivity in carbon oxidation and helps to lower the operating temperature of DCFC [29]. Cathode stability is another issue which was solved using solid oxide electrolytes [30]. The power densities of the cells comprised of YSZ-Carbonate electrolyte using carbon fuel and YSZ electrolyte, and NiYSZ anode and LSM cathode layer, was $13 \mathrm{~mW} \mathrm{~cm}^{-2}$ and $105 \mathrm{mWcm}^{-2}$, respectively, at $900{ }^{\circ} \mathrm{C}$ [31-32]. Tao et al. also prepared the DCFC with $\mathrm{ZrO}_{2}\left(\mathrm{HfO}_{2}\right)_{0.02}\left(\mathrm{Y}_{2} \mathrm{O}_{3}\right)_{0.08}$ and obtained power density of $50 \mathrm{~mW} \mathrm{~cm}{ }^{-2}$ at $1000{ }^{\circ} \mathrm{C}$ [33]. Gur et al. obtained power density of $175 \mathrm{mWcm}^{-2}-300$ $\mathrm{mWcm}{ }^{-2}$ using activated carbon in fluidized bed (FB) and fluidized coal bed- tabular $\left(24 \mathrm{~cm}^{-2}\right)$ respectively in solid oxide fuel cell at $850^{\circ} \mathrm{C}$ DCFC device at $850{ }^{\circ} \mathrm{C}[34,35]$. The fuel activated carbon, carbon black and pre-soaked needle coke produced a maximum power density of $100 \mathrm{mWcm}^{-2}, 104 \mathrm{mWcm}^{-2}$ and $187 \mathrm{mWcm}^{-2}$ at 700,850 and $650{ }^{\circ} \mathrm{C}$, respectively [36-38]. Li et al. explored the catalytic effect on gasification for DCFC using carbon black and obtained the power densities of $147.7,113.4,112.3 \mathrm{~m} \mathrm{Wcm}^{-2}$ at $750{ }^{\circ} \mathrm{C}$ with $\mathrm{Ni}, \mathrm{K}$ and $\mathrm{Ca}$ catalyst, respectively[39].

In this study LSNT $\mathrm{O}_{3-\delta}$, $\mathrm{LSFT} \mathrm{O}_{3-\delta}$, LSCT $\mathrm{O}_{3-\delta}$ and LSZT $\mathrm{O}_{3-\delta}$ anodes were prepared to examine the effect of $\mathrm{Ni}, \mathrm{Fe}, \mathrm{Co}$ and $\mathrm{Zn}$ substitution at B-site. The structural, thermal and electrical properties of the anodes were analyzed using different characterization techniques. Moreover, walnut and almond shells biochar was examined as fuel and carbon content in these biochar was analyzed using elemental analysis. On the basis of good conductivity and catalytic 
effect of $\mathrm{Ni}, \mathrm{Fe}, \mathrm{Co}$ and $\mathrm{Zn}$ these anodes have been used in DCFCs. The performance of the button cells has been measured and compared with different carbon fuels.

\section{Experimental Procedures for Materials synthesis}

\subsection{Synthesis of Anode Materials}

Anode materials $\mathrm{La}_{0.4} \mathrm{Sr}_{0.6} \mathrm{M}_{0.09} \mathrm{Ti}_{0.91} \mathrm{O}_{3-\delta}(\mathrm{M}=\mathrm{Ni}, \mathrm{Fe}, \mathrm{Co}, \mathrm{Zn})$ were synthesized using solgel technique. The chemicals $\mathrm{Sr}\left(\mathrm{NO}_{3}\right)_{2}, \mathrm{Fe}\left(\mathrm{NO}_{3}\right)_{3} .9 \mathrm{H}_{2} \mathrm{O}, \mathrm{La}\left(\mathrm{NO}_{3}\right)_{3} \cdot 6 \mathrm{H}_{2} \mathrm{O}, \mathrm{Ni}\left(\mathrm{NO}_{3}\right)_{2} 6 \mathrm{H}_{2} \mathrm{O}$, Co $\left(\mathrm{NO}_{3}\right)_{2}, \mathrm{Zn}\left(\mathrm{NO}_{3}\right)_{2} \cdot 6 \mathrm{H}_{2} \mathrm{O}$, nitric acid, citric acid, and $\mathrm{TiO}_{2}$ were purchased (Sigma Aldrich) to prepare the precursor. Appropriate amount of $\mathrm{Sr}\left(\mathrm{NO}_{3}\right)_{2}, \mathrm{Ni}\left(\mathrm{NO}_{3}\right)_{2}$ and $\mathrm{La}\left(\mathrm{NO}_{3}\right)_{3} \cdot 6 \mathrm{H}_{2} \mathrm{O}$ were mixed in deionized water and stirred at $100{ }^{\circ} \mathrm{C}$. The $\mathrm{TiO}_{2}$ was dissolved in nitric acid and stirred at $100{ }^{\circ} \mathrm{C}$ for $1 \mathrm{~h}$, and then acidic solution was mixed in nitrate solutions. The 20 mole percent citric acid was dissolved into the mixed solution. The mixture was evaporated by stirring and heating at $120^{\circ} \mathrm{C}$. The mixed solution thickened and turned into gel. Finally, the gel was burnt and turned into ash. The ash was then dried in oven for overnight at $120^{\circ} \mathrm{C}$. The final product was fired at $1200{ }^{\circ} \mathrm{C}$ for $5 \mathrm{~h}$ and after grinding final anode powder, $\left(\mathrm{LSNTO}_{3-\delta}\right)$ was obtained. The other three anodes materials $\left(\mathrm{LSNTO}_{3-\delta}, \mathrm{LSFTO}_{3-\delta}, \mathrm{LSCTO}_{3-\delta}\right.$, and $\left.\mathrm{LSZTO}_{-\delta}\right)$ were prepared using a similar method. The preparation step of the anode is shown in Fig. 2.

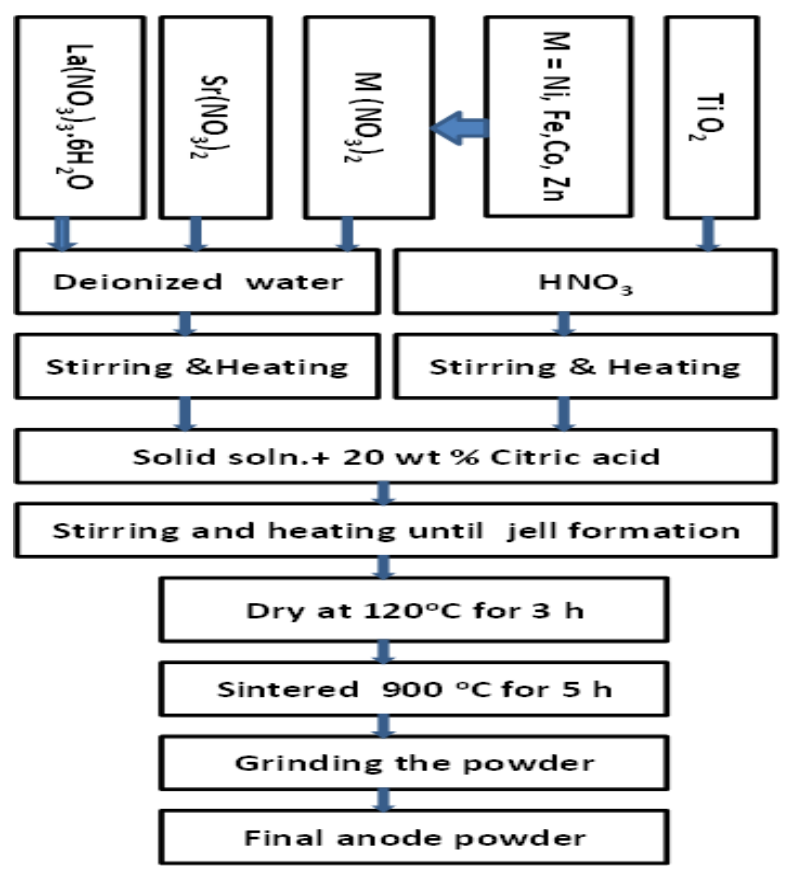

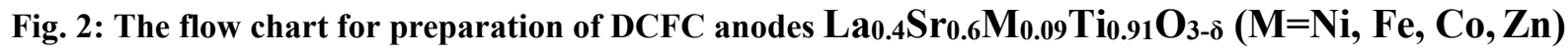




\subsection{Synthesis of Electrolyte Material}

Binary Carbonate $\left((\mathrm{Li}, \mathrm{Na})_{2} \mathrm{CO}_{3}\right)$ and doped ceria $(\mathrm{SDC})$ electrolyte named as $\mathrm{LN}-\mathrm{SDC}$ was prepared using co-precipitation method with molar ratio $2: 1$. The detailed synthesis steps were described in our previous work [40].

\subsection{Characterization}

Structural analysis of $\mathrm{La}_{0.4} \mathrm{Sr}_{0.6} \mathrm{M}_{0.09} \mathrm{Ti}_{0.91} \mathrm{O}_{3-\delta}$ anodes was examined with Bruker X-ray diffractometer using $\mathrm{Cu} \mathrm{K}_{\alpha}$ radiation. The microstructure of the sintered powders was studied using SEM (TESCAN Vega LMU). The presence of elements was examined using energy dispersive X-ray analysis. Thermal behaviors of anodes were examined by thermogravimetry analysis (model Q600, USA), and heated the sample from $50{ }^{\circ} \mathrm{C}$ to $900{ }^{\circ} \mathrm{C}$.

\subsection{Conductivity}

For conductivity measurements, pellets of thickness $0.2 \mathrm{~cm}$, diameter of $13 \mathrm{~mm}$ and active area of $0.64 \mathrm{~cm}^{2}$, were made for each sample material by hydraulic press at $300 \mathrm{MPa}$ pressure and sintered in air at $600{ }^{\circ} \mathrm{C}$ for one hour. Silver paste was glued on each side of pellet and dried at $700{ }^{\circ} \mathrm{C}$ for one hour. Conductivity of the pellet was achieved with DC four-probe (model $2450 \mathrm{SMU}$, Keithley) methods in the temperature range of $400-700{ }^{\circ} \mathrm{C}$ in air atmosphere.

\section{$2.5 \quad$ Fuel cell Design}

Walnut shell biochar fuel and LN-SDC were mixed using solid state reaction method in weight ratio 4:1. The powder containing walnut shell biochar fuel and LN-SDC was mixed in LSNTO $_{3-8}$ powder in weight ratio $45 \%: 55 \%$ to prepare composite anode. Cathode was prepared by mixing $\mathrm{LSCFO}_{3-\delta}$ and $\mathrm{LN}-\mathrm{SDC}$ in weight ratio $70 \%: 30 \%$. Similarly other composite anodes were prepared using fuel (Lignite, Bituminous, Sub-bituminous, Almond shells) and $\mathrm{LNFTO}_{3-\delta}$, $\mathrm{LSCTO}_{3-\delta}, \mathrm{LSZTO}_{3-\delta}$ powder, respectively. The Cell performance was evaluated using air as a cathode gas.

The three layer fuel cell of each material was fabricated using composite anode, LN-SDC composite electrolyte and composite cathode using dry pressing under pressure of $400 \mathrm{MPa}$.

Each pellet has a diameter of $13 \mathrm{~mm}$ and $2 \mathrm{~mm}$ thickness. The contribution of anode, electrolyte and cathode in each DCFC was $0.80 \mathrm{~mm}, 0.60 \mathrm{~mm}, 0.60 \mathrm{~mm}$ respectively. The active area of the 
cell was $0.64 \mathrm{~cm}^{-2}$. The performance was measured with a computerized instrument (S12, China) at temperature range $400-700{ }^{\circ} \mathrm{C}$.

\section{Results and Discussion}

\subsection{Structural analysis of titanate based anodes}

XRD patterns of $\mathrm{La}_{0.4} \mathrm{Sr}_{0.6} \mathrm{M}_{0.09} \mathrm{Ti}_{0.91} \mathrm{O}_{3-\delta}(\mathrm{M}=\mathrm{Ni}, \mathrm{Fe}, \mathrm{Co}, \mathrm{Zn})$ anodes fired at $1200{ }^{\circ} \mathrm{C}$ in air atmosphere for $5 \mathrm{~h}$ are shown in Fig. 3. XRD results revealed a single cubic perovskite structure (ICSD 079-0188) with space group of $\mathrm{pm} \overline{3 m}$ (221). The perovskite phase is formed during the sintering process at a temperature of $1200{ }^{\circ} \mathrm{C}[41]$.

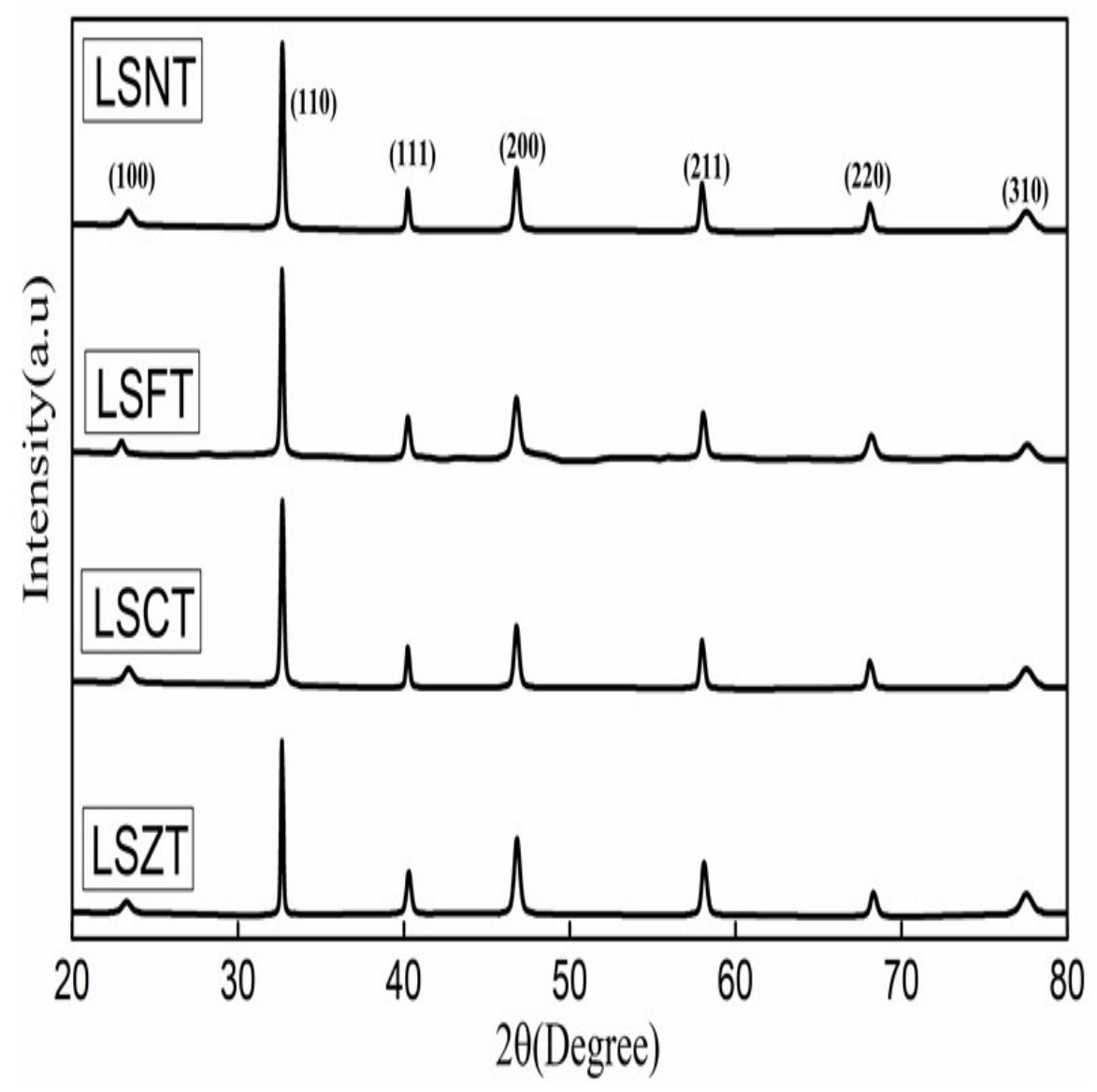

Fig. 3: XRD pattern of perovskite $\mathrm{La}_{0.4} \mathrm{Sr}_{0.6} \mathrm{M}_{0.09} \mathrm{Ti}_{0.91} \mathrm{O}_{3-\delta}(\mathrm{M}=\mathrm{Ni}, \mathrm{Fe}, \mathrm{Co}, \mathrm{Zn})$ anodes

All the peaks are of LST with no additional peaks of transition metal is observed. This reveals that the $9 \mathrm{~mol} \%$ doping of transition metals lies within the solubility limit and has successfully doped on B-site in Ti. Therefore, no peaks of transition metals were found in XRD 
results. Li et al. found that $7 \mathrm{~mol} \%$ Co doping in LST showed no peaks of cobalt [42]. Moreover from XRD data the average crystallite size was calculated by Scherer formula [43] and found to be $47 \mathrm{~nm}$.

\subsection{Microstructure and EDX analysis of the titanate based anodes}

The microstructures of the anode materials sintered at $1200{ }^{\circ} \mathrm{C}$ are shown in Fig. 4. The particles in all the microstructures show homogeneity and good porosity. The $\mathrm{LSFTO}_{3-\delta}$ anode shows excellent microstructure and good porosity compared to other samples, which may facilitate the electron transport and gas diffusion [44]. Therefore, $\mathrm{LSFTO}_{3-\delta}$ exhibited higher conductivity as well as fuel cell performance.
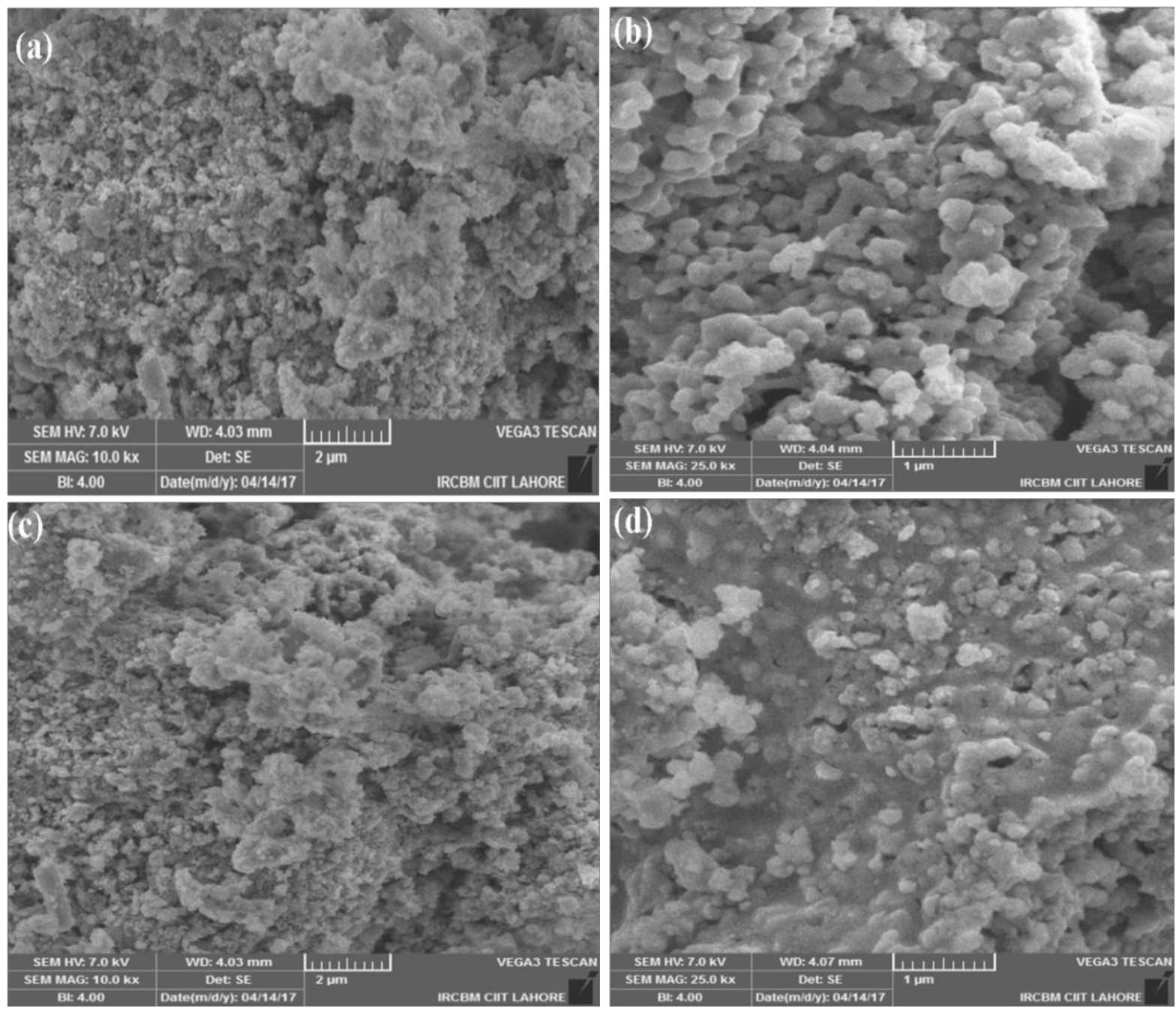

Fig. 4: SEM of the prepared anode samples (a) LSNT O3- $\delta$ (b) LSFT O3- $\delta$ (c) LSCT O3- $\delta$ (d) LSZT O3- $\delta$ 
The presence of transition metals in the prepared samples was examined using energy dispersive $x$-ray analysis (EDX) and spectrum is shown in Fig. 5. EDX confirms the distribution of $\mathrm{La}, \mathrm{Sr}, \mathrm{Ni}, \mathrm{Fe}, \mathrm{Co}, \mathrm{Zn}$ and $\mathrm{Ti}$ in the prepared anodes. The observed EDX spectrum shows that $\mathrm{Sr}, \mathrm{Ti}, \mathrm{La}$ and $\mathrm{O}$ are the main elements with traces amount of transition metal (Ni, $\mathrm{Fe}, \mathrm{Co}, \mathrm{Zn}$ ) which agree with our selected anodes concentrations $\mathrm{La}_{0.4} \mathrm{Sr}_{0.6} \mathrm{M}_{0.09} \mathrm{Ti}_{0.91} \mathrm{O}_{3-\delta}(\mathrm{M}=\mathrm{Ni}, \mathrm{Fe}, \mathrm{Co}$, $\mathrm{Zn})$. The distribution of elements in the each spectrum is found to be uniform with no agglomeration. The peaks in spectrum corresponds to $\mathrm{Sr}, \mathrm{Ti}, \mathrm{La}, \mathrm{O}$ and transition metal (Ni, Fe, $\mathrm{Co}, \mathrm{Zn}$ ), which reflect the chemical composition of the prepared anode materials.

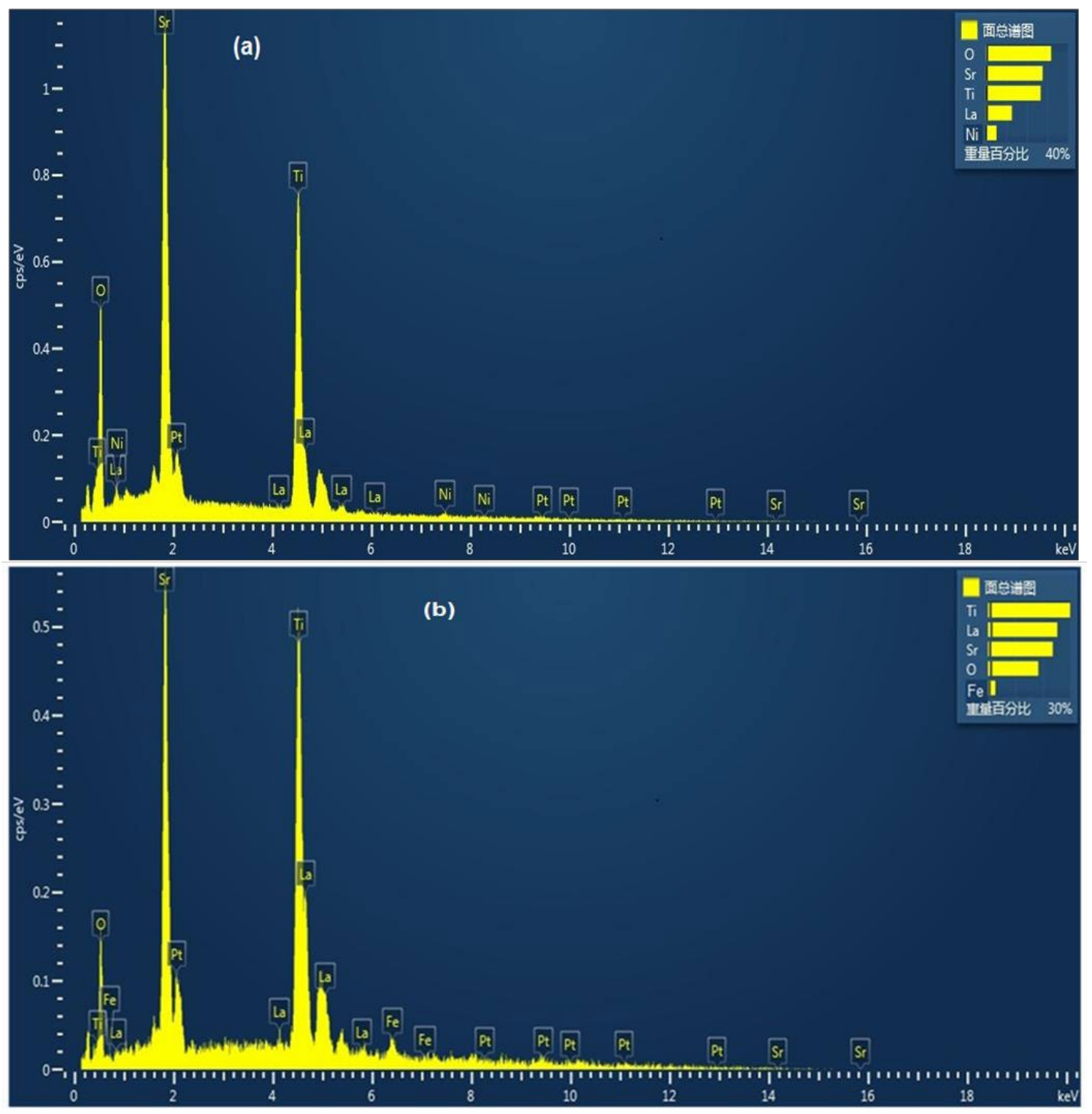


Table 1.1: The proximate and elemental analysis of Walnut and Almond shells

\begin{tabular}{|c|c|c|c|c|c|c|c|c|c|c|}
\hline \multirow{2}{*}{ Sample } & \multicolumn{4}{|c|}{ Proximate analysis wt. \% } & \multicolumn{4}{|c|}{ Elemental/Ultimate analysis wt. \% } & \multirow{2}{*}{ MJ/kg } \\
\cline { 2 - 10 } & FC & VM & Ash & M & C & N & H & S & O & \\
\hline $\begin{array}{c}\text { Walnut } \\
\text { shells }\end{array}$ & 61.47 & 14.25 & 18.5 & 5.78 & 69.6 & 1.60 & 3.98 & 2.76 & 22.06 & 24.33 \\
\hline $\begin{array}{c}\text { Almond } \\
\text { shells }\end{array}$ & 59.15 & 15.7 & 19.20 & 5.95 & 66.5 & 1.75 & 4.12 & 3.47 & 24.16 & 23.06 \\
\hline
\end{tabular}

\subsection{Fuel analysis}

The walnut and almond shells biochar fuel was used in DCFCs and carbon content which determines the efficiency of fuel was examined with proximate and elemental analysis. The proximate and elemental analysis of walnut and almond shells biochar fuels are shown in Table 1.1. 
The carbon content, which estimates the heating values, was found to be $70 \%$ and $67 \%$ in walnut and almond shells. The carbon contents are higher than lignite $51 \%$, bituminous coal $62 \%$ but lower than sub-bituminous coal $72 \%$ [45]. The calorific value of the walnut and almond shells were calculated using formula [46] given below:

$$
\Delta H=1.3675+0.3137 \times C+0.7009 \times H+0.0318 \times O
$$

and $\Delta H$ values for both fuels are shown in Table 1.

Fig. 6 (a-b): shows the microstructure of the biochar fuel obtained from walnut and almond shells, respectively. The particles of prism-like and cylindrical shapes were found from SEM analysis.
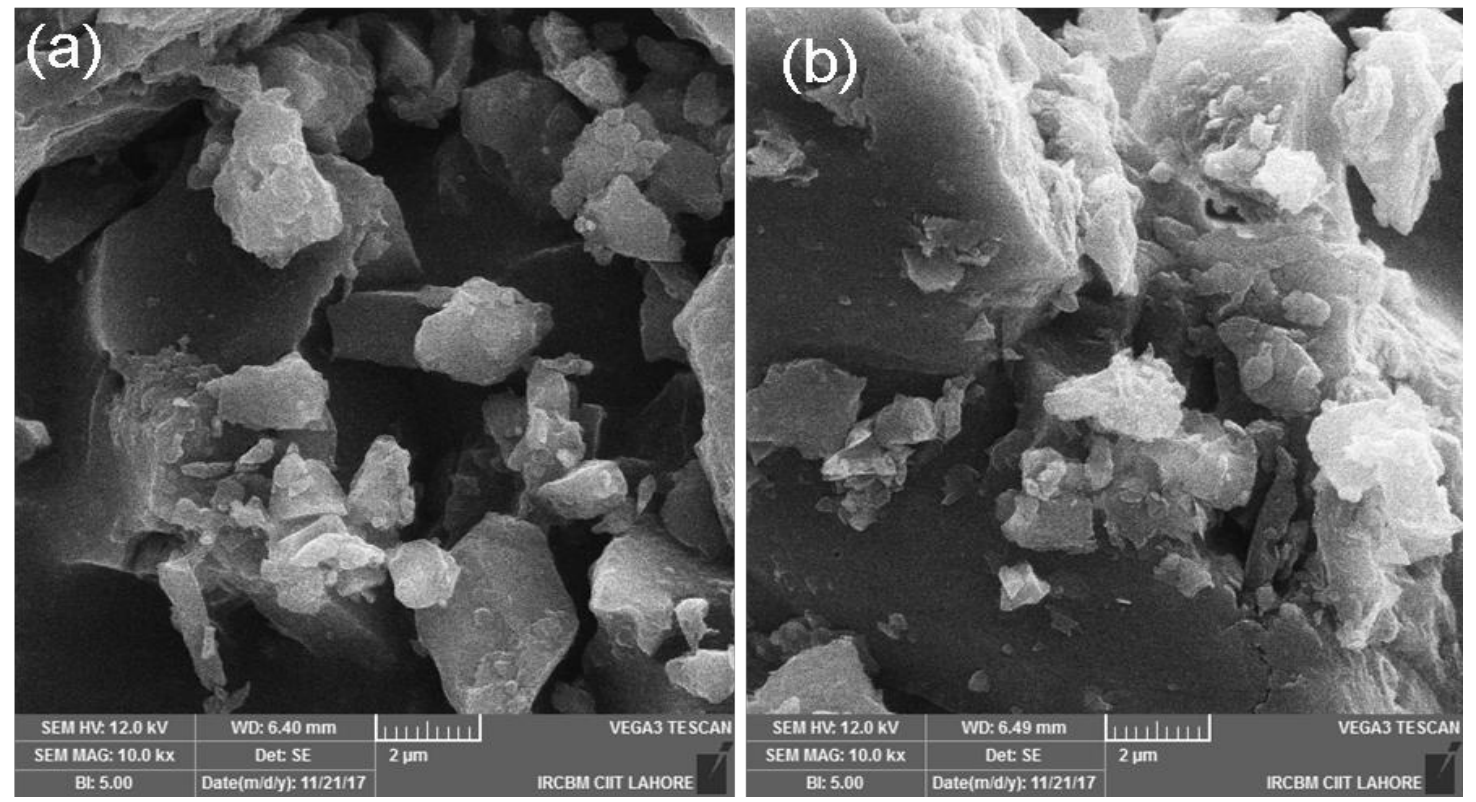

Fig. 6: Microstructure of the biochar fuel obtained from (a) walnut shells (b) almond shells

\subsection{Thermal analysis of titanate based anodes}

Thermal analysis, which describes the thermal stability of the materials, was carried from 50-900 ${ }^{\circ} \mathrm{C}$ and is shown in Figure 7. Thermal analysis is spanned over three regions in the temperature ranges $50-350{ }^{\circ} \mathrm{C}, 350-680{ }^{\circ} \mathrm{C}$ and $680-900{ }^{\circ} \mathrm{C}$, respectively. The region I describe the weight loss due to the water adsorbed in the materials [47]. The composition LSFTO$_{3-\delta}$ has the lowest weight loss of $0.35 \%$ while $\mathrm{LSCTO}_{3-\delta}$ has higher weight loss compared to other compositions. The melting of carbonates and decomposition is the result of the weight loss in 
region II. The composition $\mathrm{LSFTO}_{3-\delta}$ has very small weight loss in this region which may be the reason of higher conductivity and fuel cell performance. The loss in the lattice oxygen is the reason of weight loss in the region III [48]. In this region $\mathrm{LSFTO}_{3-\delta}$ has $0.56 \mathrm{wt} \%$ while $\mathrm{LSZTO}_{3-\delta}$ has $1.31 \mathrm{wt} \%$ weight losses.

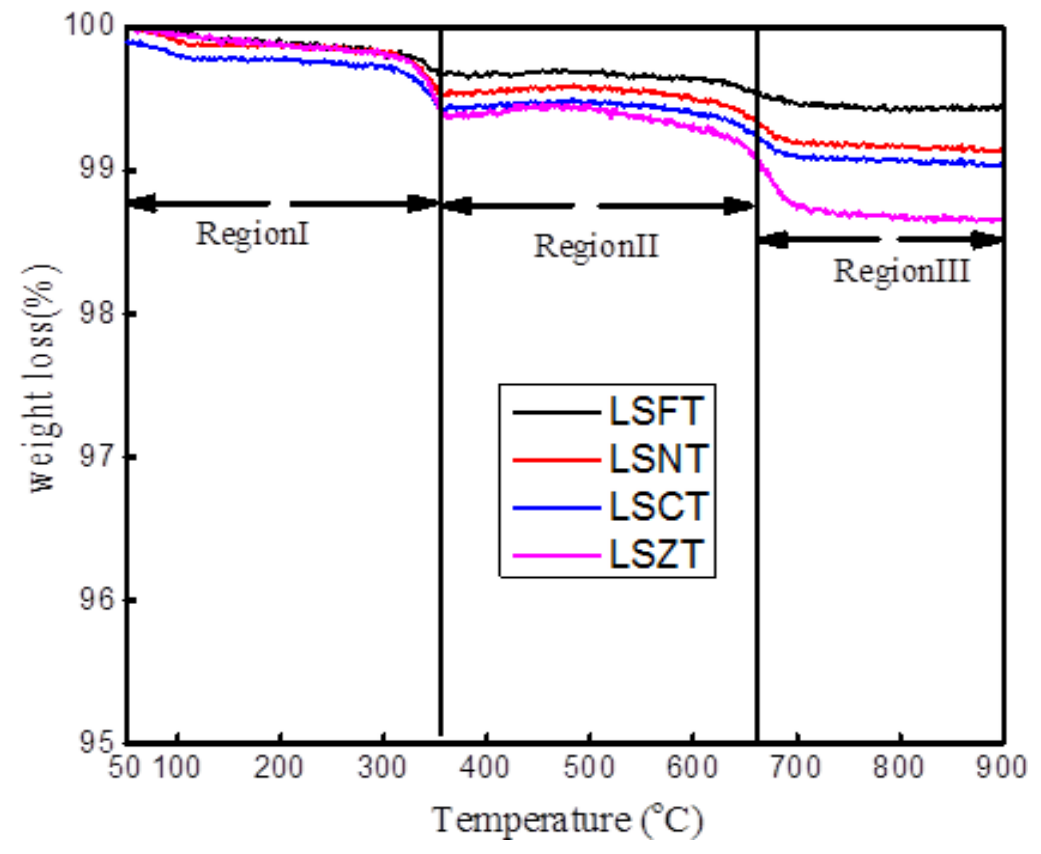

Fig. 7: Thermal analysis of titanate based anodes

\subsection{Conductivity of titanate based anodes}

To obtain good conductivity and performance of the materials, the materials must possess sufficient thermal stability and compatibility at a desired temperature. The electrical conductivity was examined in air atmosphere using four probe DC techniques in the temperature range 400$700{ }^{\circ} \mathrm{C}$ and shown in Table 2. The results shows that $\mathrm{LSFTO}_{3-\delta}$ has the highest conductivity of $7.53 \mathrm{Scm}^{-1}$ compared to $\mathrm{LSNTO}_{3-\delta}, \mathrm{LSCTO}_{3-\delta}$ and $\mathrm{LSZTO}_{3-\delta}$. The highest conductivity of $\mathrm{LSFTO}_{3-\delta}$ may be due to better porosity as seen by Fig. 4 (b) compared to others. From the conductivity data Arrhenius graph was plotted shown in Fig. 8 for activation energy calculation. The activation energies of the prepared anodes are shown in Table 2. The conductivity of $\mathrm{LSNTO}_{3-\delta}$ increases with temperature increase compared to $\mathrm{LSFTO}_{3-\delta}, \mathrm{LSCTO}_{3-\delta}, \mathrm{LSZTO}_{3-\delta}$, but at a temperature of $700{ }^{\circ} \mathrm{C}$ it decreases compared to $\mathrm{LSFTO}_{3-\delta} \quad$ which has highest conductivity of $7.53 \mathrm{Scm}^{-1}$. The increase in conductivity at temperature may be due to the 
sintering at $1200{ }^{\circ} \mathrm{C}$, which increase the contact between particles. The increase in conductivity with temperature reveals the semiconductor behavior. The reported conductivity of $\mathrm{LSCTO}_{3-\delta}$ anode is $16-18 \mathrm{Scm}^{-1}$ at $800{ }^{\circ} \mathrm{C}$ [49]. Li et al. measured the electrical conductivity $\left(63 \mathrm{Scm}^{-1}\right.$ at $700{ }^{\circ} \mathrm{C}$ ) of the composition $\mathrm{La} \quad{ }_{0.3} \mathrm{Sr}_{0.7} \mathrm{Co}_{0.07} \mathrm{Ti}_{0.93} \mathrm{O}_{3-\delta}$ [32]. The mixed ionic and electronic conductors MIECs have much higher electronic conductivity compared to ionic conductivity [50]. Therefore, electronic conductivity has a major role in the performance of the cell.

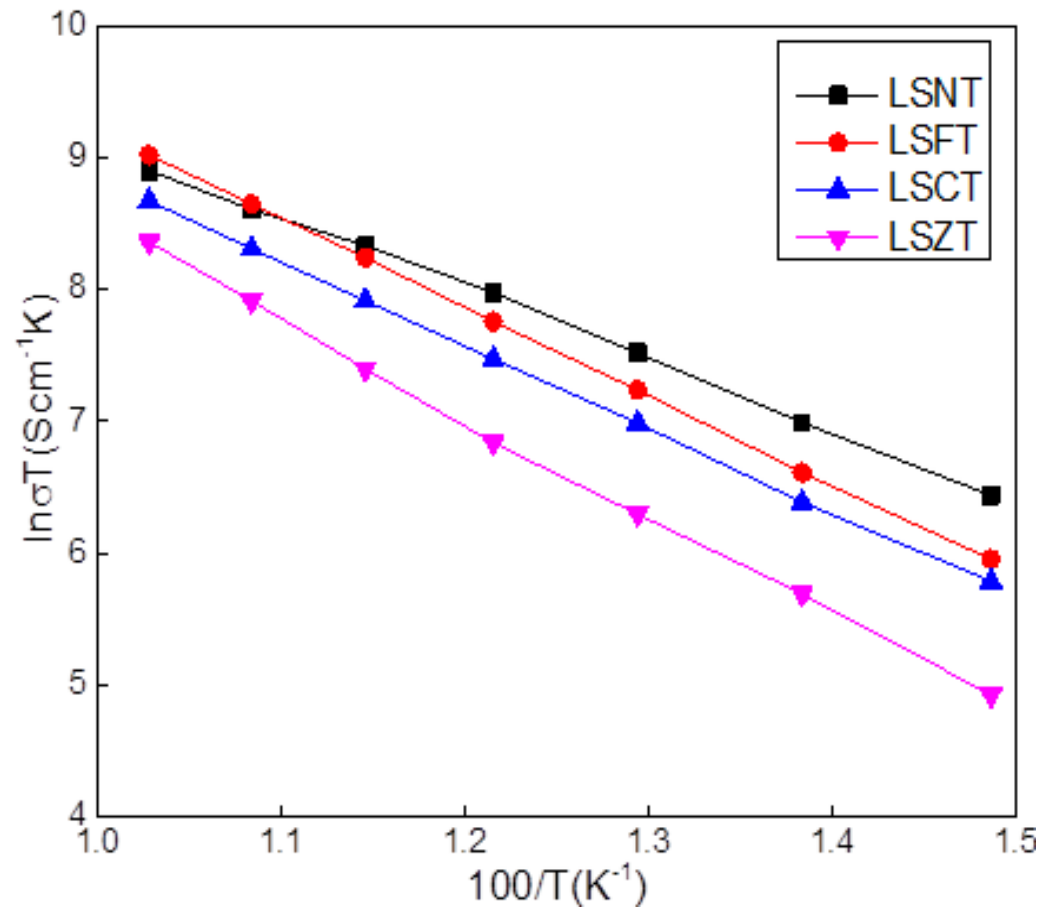

Fig. 8: Arrhenius plot of titanate based anodes

Table 2: Conductivity, activation energy and power density of the titanate based anodes

\begin{tabular}{|c|c|c|c|c|c|}
\hline Samples & $\begin{array}{c}\sigma\left(\mathrm{Scm}^{-1}\right) \\
@ 700{ }^{\circ} \mathrm{C}\end{array}$ & $\begin{array}{c}\mathrm{E}_{\mathrm{a}} \mathrm{eV} \\
\left(400-700{ }^{\circ} \mathrm{C}\right)\end{array}$ & \multicolumn{3}{|c|}{$\begin{array}{c}\text { Power density }\left(\mathrm{mWcm}{ }^{-2}\right) \text { with } \\
\text { multi-fuels } @ 700{ }^{\circ} \mathrm{C}\end{array}$} \\
\hline \multirow{2}{*}{ LSNT O $_{3-\delta}$} & 7.02 & 0.53 & $\begin{array}{c}\text { Sub- } \\
\text { bituminous }\end{array}$ & $\begin{array}{c}\text { Walnut shell } \\
\text { biochar }\end{array}$ & $\begin{array}{c}\text { Almond shell } \\
\text { biochar }\end{array}$ \\
\cline { 3 - 6 } & & & 54 & 51 & 41 \\
\hline LSFT O $_{3-\delta}$ & 7.53 & 0.50 & 68 & 55 & 44 \\
\hline LSCT O$_{3-\delta}$ & 6.01 & 0.55 & 51 & 48 & 39 \\
\hline LSZT O $_{3-\delta}$ & 4.28 & 0.62 & 28 & 30 & 25 \\
\hline
\end{tabular}




\subsection{Electrochemical performance of the titanate based anodes}

Generally, a DCFC operates at higher temperature and thus the thermal stability of the materials at higher temperature is a key issue. Therefore, such materials are needed which are thermally stable. The electrochemical performance of the button cells using LN-SDC electrolyte and already published cathode $\mathrm{LSCFO}_{3-\delta}$ along with prepared anodes are shown in Fig. 9(a-c) using sub-bituminous, walnut shell and almond shell biochar carbon at $700{ }^{\circ} \mathrm{C}$. In this study, composite electrolyte (LN-SDC) is used but at cathode only air is provided so conduction is due to only $\mathrm{O}^{2-}$ ions. But if air and $\mathrm{CO}_{2}$ is provided at cathode then both $\mathrm{O}^{2-}$ and $\mathrm{CO}_{3}^{2-}$ ions will produce at cathode and both ions conduct through the electrolyte and performance will be increased [32].

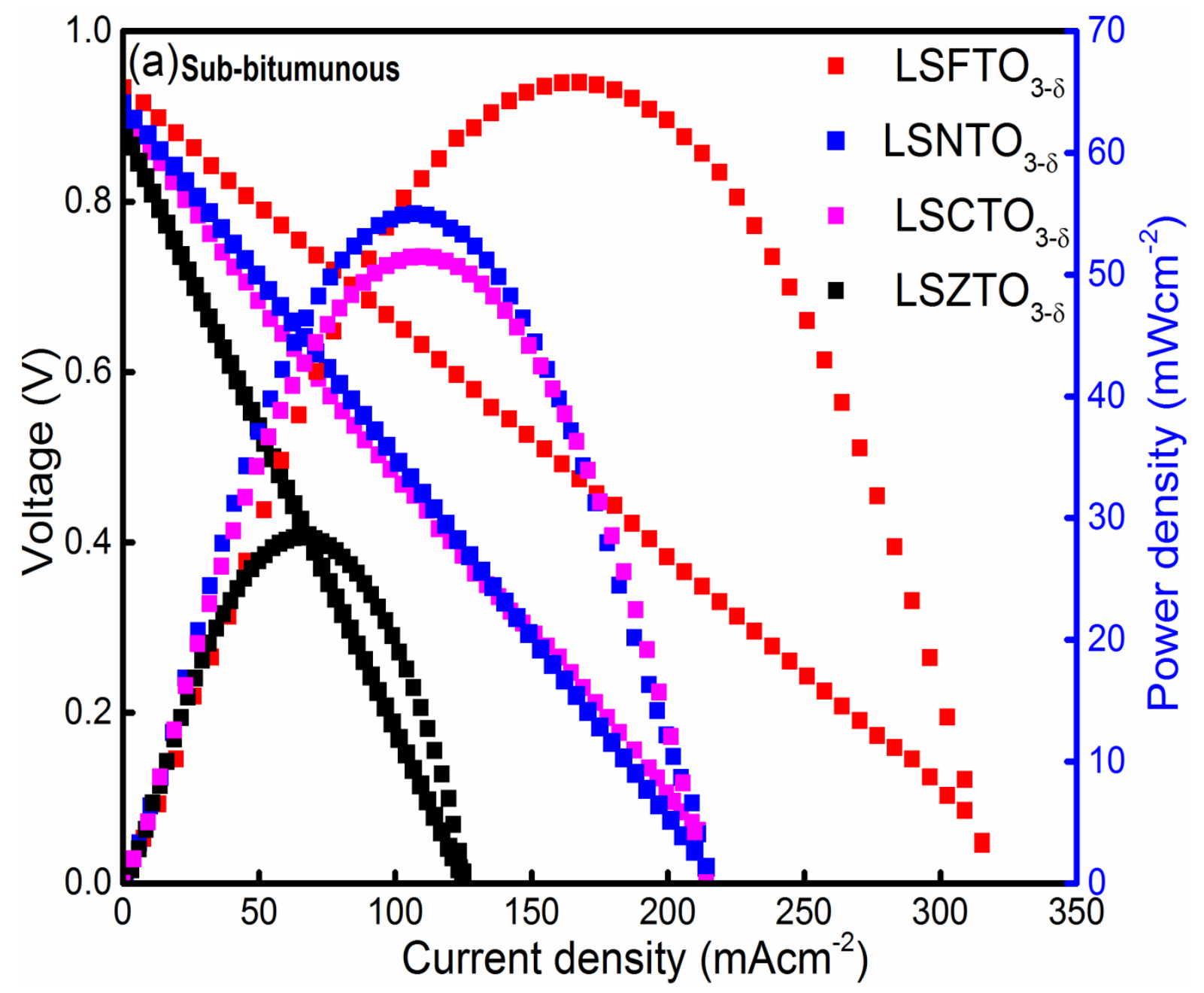



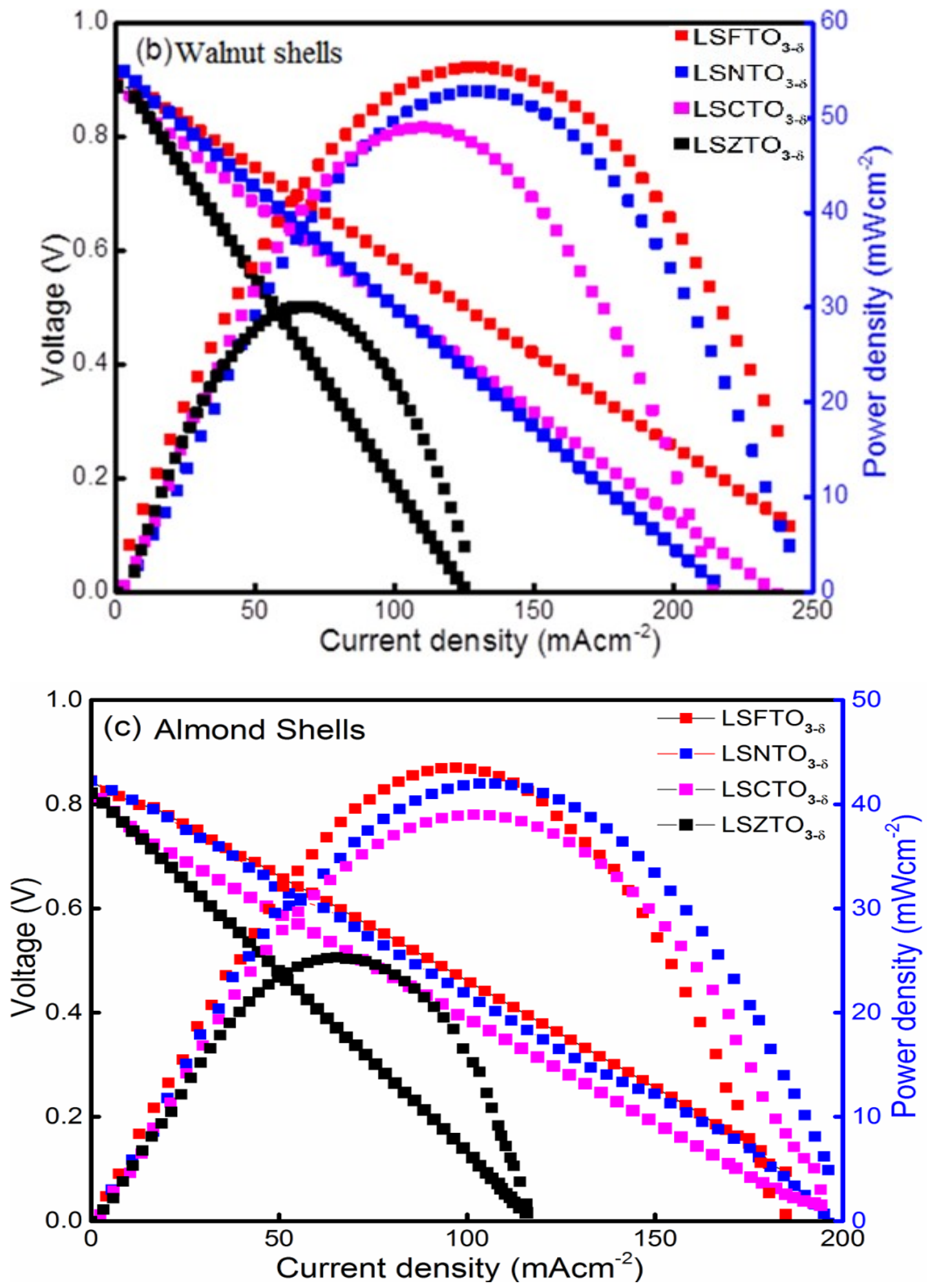

Fig. 9: Performance of the cells at $700{ }^{\circ} \mathrm{C}$ with titanate based anodes using (a) sub-bituminous coal fuel (b) walnut shells biochar fuel (c) almond shells biochar fuel 
The $\mathrm{LSFTO}_{3-\delta}$ shows the maximum peak power density of $68 \mathrm{mWcm}^{-2}$ and OCV of 0.93 $\mathrm{V}$ at $700{ }^{\circ} \mathrm{C}$ compared to $\mathrm{LSNTO}_{3-\delta}, \mathrm{LSCTO}_{3-\delta}$ and $\mathrm{LSZTO}_{3-\delta}$ respectively. Power density of the cell with $\mathrm{LSFTO}_{3-\delta}$ anode mixed in walnut shells is $55 \mathrm{mWcm}^{-2}$ higher than almond shells biochar fuel $\left(44 \mathrm{mWcm}^{-2}\right)$ but lower than Sub-bituminous coal $\left(68 \mathrm{mWcm}^{-2}\right)$ at $700{ }^{\circ} \mathrm{C}$. Elleuch et al. measured a power density of $150 \mathrm{mWcm}^{-2}$ using NiO-SDC anode mixed in almond shells at 700 ${ }^{\circ} \mathrm{C}$ [51]. An et al. measured a peak power density approximately $191 \mathrm{mWcm}^{-2}$ at $850{ }^{\circ} \mathrm{C}$ using catalyzed bamboo biochar fuel [52].

\subsection{Best electrolyte and electrodes performance}

The results revealed that electrolyte $\mathrm{LN}-\mathrm{SDC}, \mathrm{LSFTO}_{3-\delta}$ anode and $\mathrm{LSCFO}_{3-\delta}$ cathode is the best for DCFCs. Therefore, a single cell composed of composite anode ( $\left.\mathrm{LSFTO}_{3-\delta}\right)$, LN-SDC electrolyte and composite cathode $\left(\mathrm{LSCFO}_{3-\delta}\right)$ was tested and its performance is shown in Fig. 10.

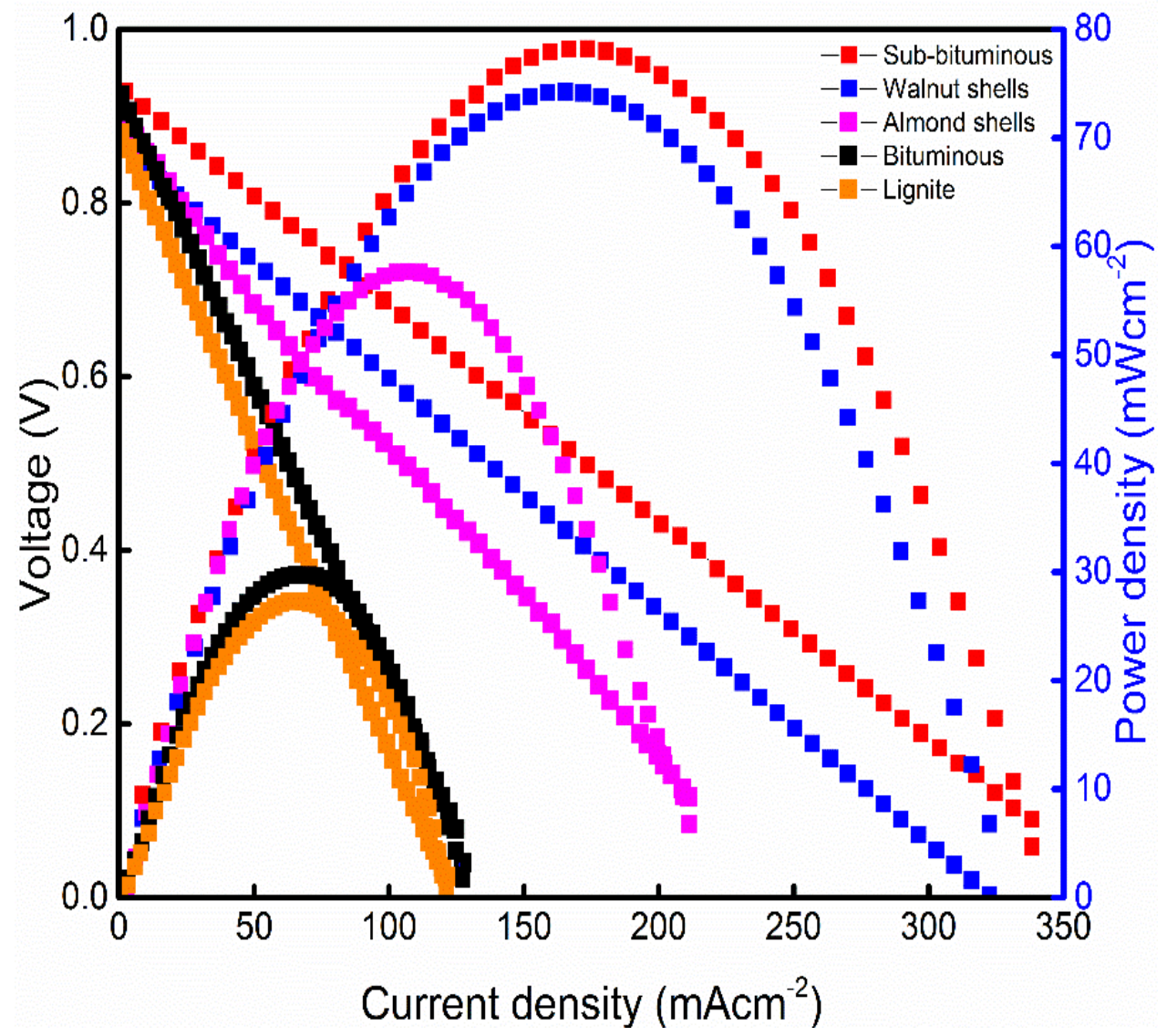

Fig. 10: Electrochemical performance of the best electrolyte, anode and cathode using different fuels 
The electrochemical performance of cells have been achieved 78, 73, 57, 29 and $26 \mathrm{mWcm}^{-2}$ at $700{ }^{\circ} \mathrm{C}$ using sub-bituminous, walnut shells, almond shells, bituminous and lignite fuels, respectively. This increased cell performance is due to the catalyst iron which is economical and effective catalyst for carbon gasification [53]. This performance shows that the prepared materials can be used in DCFCs for electricity generation.

Fig. 11 shows the durability/stability test of the cells which was conducted to analyze the feasibility of the device. During the operation cell 1 shows higher voltage than cell 2 . This test was performed after evaluation the fuel cell performance. Both devices show adequate stability during the $36 \mathrm{~h}$ operation at $700{ }^{\circ} \mathrm{C}$. . The current densities of both cells during the measurements have been found to be $90 \mathrm{mAcm}^{-2}$ and $84 \mathrm{mAcm}^{-2}$ at $700{ }^{\circ} \mathrm{C}$.

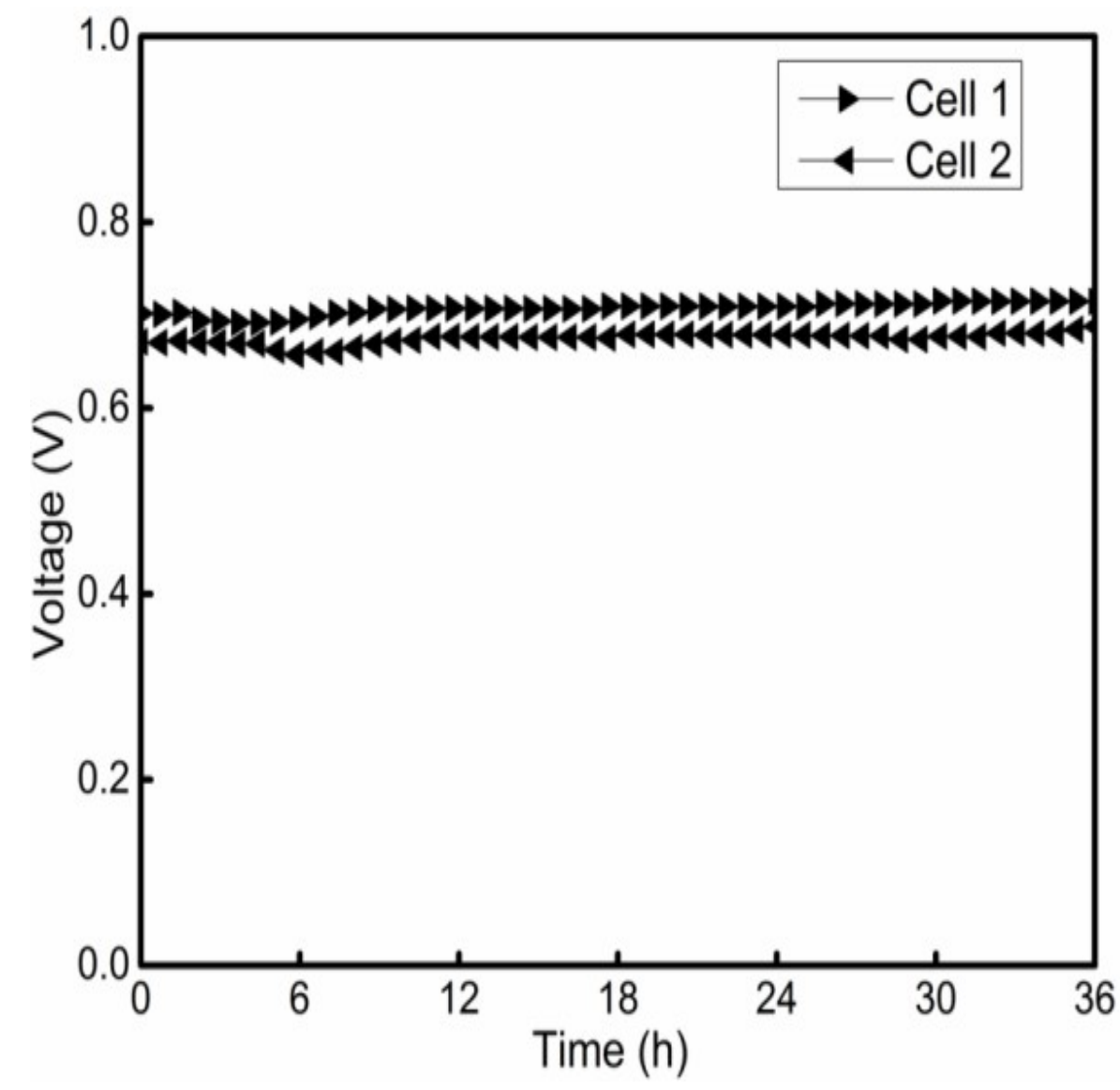

Fig. 11: Stability test of the cells at $700{ }^{\circ} \mathrm{C}$ 

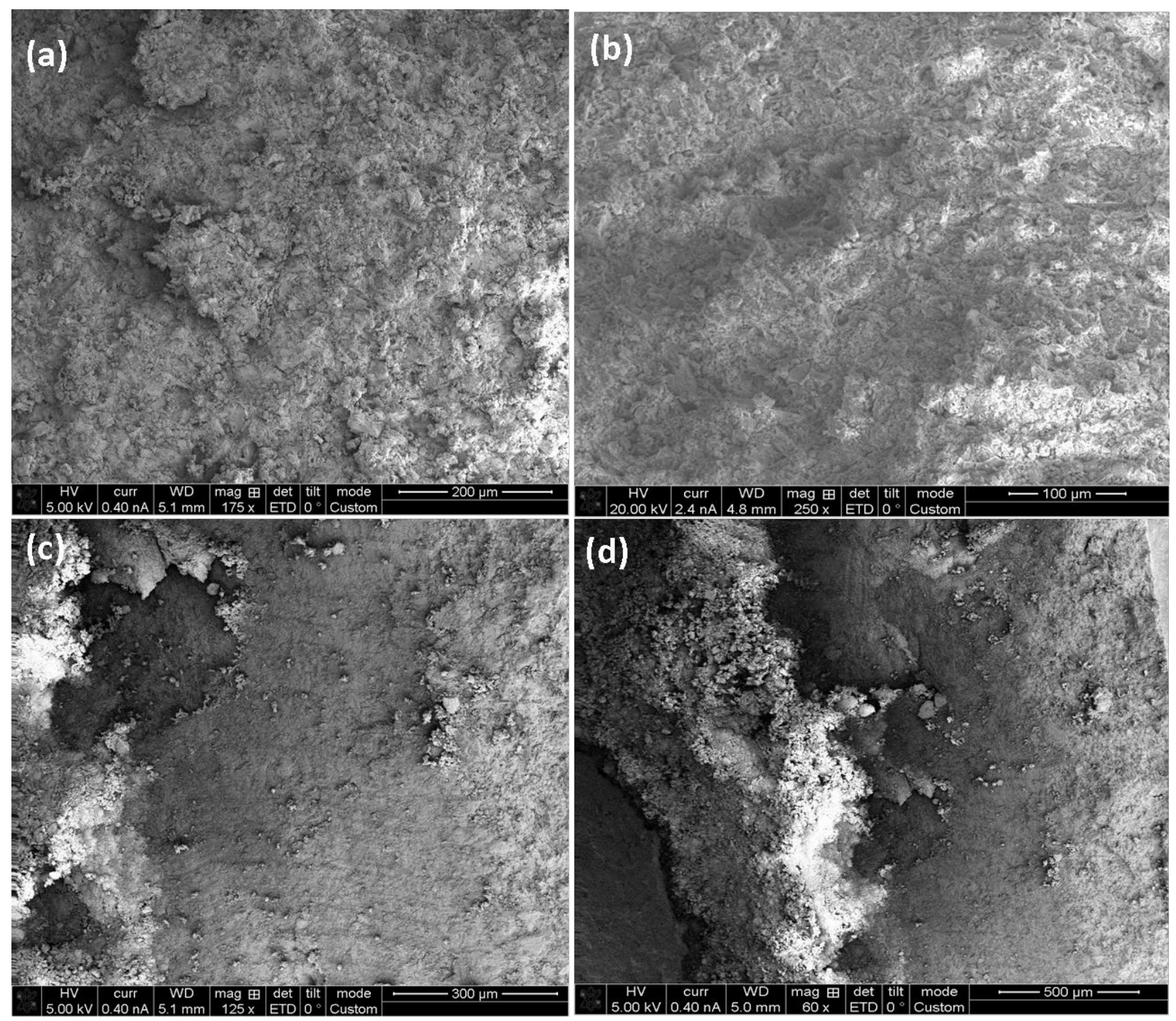

Fig. 12: Microstructure of the composite anodes after test (a) $\mathrm{LSNTO}_{3-\delta}$ (b) $\mathrm{LSFTO}_{3-\delta}$ (c) $\mathrm{LSCTO}_{3-\delta}$ (d) $\operatorname{LSZTO}_{3-\delta}$

Fig. 12 shows the microstructure of the anode after the performance test. The microstructure shows that anodes have been reduced in the carbon environment. The $\mathrm{LSFTO}_{3-\delta}$ anode exhibited better microstructure so gave maximum power density.

\section{Conclusions}

In this work, titanate based anodes $\mathrm{La}_{0.4} \mathrm{Sr}_{0.6} \mathrm{M}_{0.09} \mathrm{Ti}_{0.91} \mathrm{O}_{3-\delta}(\mathrm{M}=\mathrm{Ni}, \mathrm{Fe}, \mathrm{Co}, \mathrm{Zn})$ have been synthesized by sol-gel technique to study the crystal structure, conductivity, stability and 
performance of the device. The titanate based anode shows cubic perovskite structure with space group of $p m \overline{3} m$ (221). The $\mathrm{LSFTO}_{3-\delta}$ anode has greater electronic conductivity of $7.53 \mathrm{Scm}^{-1}$ at $700{ }^{\circ} \mathrm{C}$ than $\mathrm{LSNTO}_{3-\delta}, \mathrm{LSCTO}_{3-\delta}$ and $\mathrm{LSZTO}_{3-\delta}$. The peak power density of $78 \mathrm{mWcm}{ }^{-2}$ has been obtained using $\mathrm{LSFTO}_{3-\delta}$ anode composite, $\mathrm{LSCFO}_{3-\delta}$ cathode and $\mathrm{LN}-\mathrm{SDC}$ electrolyte at $700{ }^{\circ} \mathrm{C}$ for sub-bituminous coal fuel. Furthermore $\mathrm{LSFTO}_{3-\delta}$ anode has shown a good and remarkable stability during $36 \mathrm{~h}$ of operation. The $\mathrm{O}^{2-}$ ions conduction mechanism has been discussed during the cell operation due to air at cathode. Therefore, all of the prepared materials in this study have significant potential to be used as a prime choice for electrodes in DCFCs for power generation.

\section{References}

[1] C.Li, Y. Shi, N. Cai. J. Power Sources 195(2010) 4660-4666.

[2] C.Li, E.K.Lee, Y.T.Kim, D. Lee, Int.J. Hydrogen Energy 39 (2014) 17314-17321.

[3] Y.Jiao, X.Xue, W. An, P.S.B. Julião, W.Wang, G. Yang, S.D. Li, In. J. Energy Res. (2018) 13.

[4] W.An, X. Sun, Y. Jiao, P.S.B. Julião, W. Wang, S. Wang, S. Shuang, In. J. Energy Res. (2018). DOI: 10.1002/er.4097.

[5] L.Deleebeeck, D. Ippolito, K.K. Hansen, Electrochimica Acta. 152(2015) 152, 222-239.

[6] A.C.Chien, S.S.Chuang, J. Power Sources196 (2011) 4719-4723.

[7] S.Giddey, S.P.S. Badwal, A. Kulkarni, C. Munnings, Progress in Energy and Combustion Science 38(2012) 360-399.

[8] W.Wu, F. Ding, M. Fan, T. He, ECS Transactions 78(2017) 2519-2526.

[9] A.Kulkarni, S. Giddey, S.P.S.Badwal, J. Solid State Electrochemistry 19(2015) 325-335.

[10] D.Cao, Y.Sun, G. Wang, J. Power Sources 167(2007) 250-257.

[11] J.Ruflin, A.D. Perwich II, C. Brett, J.K. Berner, S.M. Lux, J. Power Sources 213(2012) 275-286. 
[12] B.Yang, R.Ran, Y. Zhong, C. Su, M.O.Tadé, Z. Shao, Angewandte Chemie 127(2015) 3793-3796.

[13] X.Xu, W. Zhou, F. Liang, Z. Zhu, Int. J. Hydrogen Energy, 38(2013) 5367-5374.

[14] W.Li, C.Y. Xiong,L.C. Jia, J. Pu, B. Chi, X. Chen, X., J. Li, J.Power Sources, 284(2015) $272-278$.

[15] H.V.PNguyen, M.G. Kang, H.C Ham, S.H.Choi, J. Han, S.W. Nam, S.P. Yoon, J. Electrochemical Society 161(2014) F1458-F1467.

[16] S.McIntosh, R.J. Gorte, Chemical reviews 104(2004) 4845-4866.

[17] A.Atkinson, S Barnett, R.J. Gorte, J. T. S.Irvine, A.J. McEvoy, M. Mogensen, J. Vohs, In Materials for Sustainable Energy: A Collection of Peer-Reviewed Research and Review Articles from Nature Publishing Group (2011) 213-223.

[18] J. T. S. Irvine, Perovskite oxide anodes for SOFCs. In Perovskite Oxide for Solid Oxide Fuel Cells (pp. 167-182). Springer, Boston, MA (2009).

[19] P.I.Cowin, C.T. Petit, R. Lan, J.T.S. Irvine, S. Tao, Advanced Energy Materials 1(2011) 314-332.

[20] E.P.Murray, T. Tsai, S.A. Barnett, Nature 400(1999) 649.

[21] O.A. Marina, C. Bagger, S. Primdahl, M. Mogensen, Solid State Ionics, 123(1999) 199208.

[22] K.B.Yoo, G.M. Choi, Solid State Ionics 11(2009) 867-871.

[23] X.Sun, S. Wang, Z.Wang, X. Ye, T. Wen, F. Huang, J. Power Sources 183(2008) 114-117.

[24] S.Lee,G. Kim, J.M.Vohs, R.J. Gorte, J. Electrochemical Society 155(2008) B1179-B1183.

[25] C.H.Law, S.W. Sofie, J. Electrochemical Society 158(2011) B1137-B1141.

[26] L.Yang,L.C. De Jonghe, C.P.Jacobsen, S.J. Visco, J. Electrochemical Society 154(2007) B949-B955.

[27] J.F. Cooper, N. Cherepy, R.L. Krueger, US Patent 6,878,479 (2005).

[28] J.F. Cooper, Direct conversion of coal derived carbon in fuel cells. In Recent trends in fuel cell science and technology (pp. 248-266). Springer, New York, NY 2003.

[29] S. Zecevic, E.M. Patton, P. Parhami, Carbon 42(2004) 1983-1993.

[30] C.Xia, Y. Li, Y., Tian, Q. Liu, Y. Zhao, L. Jia, Y. Li, J. Power Sources 188(2009) 156-162. 
[31] S.L.Jain, J.B. Lakeman, K.D. Pointon, J.T.S. Irvine, J.Fuel Cell Science and Technology 4(2007) 280-282.

[32] T.T.Tao, (2004). U.S. Patent No. 6,692,861 (2004).

[33] H.Ju, S. Uhm,J.W. Kim, R.H. Song, H. Choi,S.H. Lee, J. Lee, J. Power Sources 198(2012) $36-41$.

[34] T.M.Gür, J. Electrochemical Society 157(2010) B751-B759.

[35] T.M. Gür, M. Homel, A.V. Virkar, J. Power Sources 195(2010) 1085-1090.

[36] L. Jia, Y. Tian, Q. Liu, C. Xia, J. Yu, Z. Wang, Y. Li, J. Power Sources, 195(2010), 55815586.

[37] R.Liu, C. Zhao, J. Li, F. Zeng, S. Wang, T. Wen, Z. Wen, J. Power Sources 195(2010) 480482.

[38] M. Chen, C. Wang, X. Niu, S. Zhao, J. Tang, B. Zhu, Int. J. Hydrogen Energy 35(2010) 2732-2736.

[39] C. Li, Y. Shi, N. Cai, J. Power Sources 195(2010) 4660-4666.

[40] A.Ali, A. Rafique, M. Kaleemullah, G. Abbas, M. Ajmal Khan, MM.A. Ahmad, R. Raza, ACS applied materials \& interfaces 10(2018) 806-818.

[41] L.Zhang, J. Xiao, Y. Xie, Y. Tang, J.Liu, M. Liu J. Alloys and Compounds 608 (2014) 272-277.

[42] X. Li,H. Zhao,N. Xu, X. Zhou, C. Zhang, N. Chen, Int. J. Hydrogen Energy 34(2009) 6407-6414.

[43] C.Yuan, Y. Zhou, J. Qian, X. Ye, Z. Zhan, S. Wang, Materials Research Innovations 18(2014) S4-132.

[44] A. Ali, F.S. Bashir, R. Raza, A. Rafique, M.K. Ullah, F. Alvi, L.M. Belova, Int. J. Hydrogen Energy 43(2018) 12595-12916.

[45] A. Elleuch, K. Halouani, Y. Li, J. Power Sources 281(2015) 350-361. 
[46] S.Li, Z. Lü, X. Huang,B. Wei, W. Su, Solid State Ionics 178(2007) 417-422.

[47] N. Mushtaq, C. Xia, W. Dong, G. Abbas, R. Raza, A. Ali, B. Zhu, Ceramics International 44(2018) 10266-10272.

[48] A. Kulkarni, S. Giddey, S.P.S. Badwal, G. Paul, Electrochimica Acta. 121(2014) 34-43.

[49] H.Yokokawa, N. Sakai, T. Kawada, M. Dokiya, Solid State Ionics 52(1992) 43-56.

[50] A.Elleuch, A. Boussetta, J. Yu, K. Halouani, Y. Li, Int .J. Hydrogen Energy 38(2013) 16590-16604.

[51] A.Elleuch, A. Boussetta, K.Halouani, Y. Li, Int. J. Hydrogen Energy 38(2013) 1660516614.

[52] W. An, X. Sun, Y. Jiao, S. Wang, W. Wang, M.O. , S. Shuang, Energy \& Fuels 32(2018) 4559-4568.

[53] Y. Bai, Y. Liu, Y. Tang, Y. Xie, J. Liu, Int .J. Hydrogen Energy 36(2011) 9189-9194. 